\title{
PENGARUH KEDISIPLINAN DAN EFIKASI GURU TERHADAP KINERJA GURU DIMODERASI SUPERVISI KEPALA SEKOLAH DI SMA KABUPATEN JEPARA
}

\author{
SUGENG \\ SMA Negeri 1 Mayong \\ e-mail: sugengpati@gmail.com
}

\begin{abstract}
ABSTRAK
Tujuan penelitian adalah untuk menguji pengaruh kedisiplinan dan efikasi guru terhadap kinerja guru dimoderasi supervisi kepala sekolah di SMA Kabupaten Jepara. Populasi guru SMA kirakira 709 lebih dengan pengambilan sampel accidental sampling. Sampel bersifat homogin sebanyak 95 guru. Metode yang digunakan dalam pengumpulan data adalah menggunakan kuesener. Teknik pengumpulan data melalui penyebaran angket kuesener dengan skala likert 1 sampai 5. Metode analisis data dengan mendeskriptifkan kharakteristik responden meliputi jenis kelamin, usia, pendidikan, golongan, dan masa kerja. Sementara analisis modelnya menggunakan moderasi selisih mutlak yakni analisis variabel moderasi dengan meregresikan selisih mutlak. Pada hasil 1) Kedisiplinan berpengaruh positif dan signifikan terhadap kinerja guru 2) Efikasi guru berpengaruh positif dan signifikan terhadap kinerja guru, 3) Supervisi kepala sekolah tidak memoderasi pengaruh kedisiplinan terhadap kinerja guru ,dan 4) Supervisi kepala sekolah tidak memoderasi efikasi guru terhadap kinerja guru. Dengan demikian masih diperlukan penelitian sejenis dengan populasi dan sampel berbeda.
\end{abstract}

Kata kunci : Kedisiplinan, efikasi guru, kinerja , supervisi

\section{ABSTRACT}

The purpose of the study was to examine the effect of teacher discipline and efficacy on teacher performance moderated by the supervision of the principal at SMA Kabupaten Jepara. The population of high school teachers is approximately 709 more with accidental sampling. The sample is homogeneous as many as 95 teachers. The method used in data collection is using a questionnaire. The data collection technique was through the distribution of questionnaires with a Likert scale of 1 to 5. The method of data analysis was to describe the characteristics of the respondents including gender, age, education, class, and years of service. While the model analysis uses absolute difference moderation, namely the analysis of moderating variables by regressing the absolute difference. In the results 1) Discipline has a positive and significant effect on teacher performance 2) Teacher efficacy has a positive and significant effect on teacher performance, 3) Principal supervision does not moderate the effect of discipline on teacher performance, and 4) Principal supervision does not moderate teacher efficacy on teacher performance. . Thus, similar research is still needed with different populations and samples.

Keywords: Discipline, teacher efficacy, performance and supervision of the principal

\section{PENDAHULUAN}

Untuk meningkatkan manajemen kedisiplinan, kepala sekolah dapat melakukan kebijakan seperti melakukan pengawasan. Seperti Penelitian oleh Ardansyah dan Wasilawati menyimpulkan sebagai berikut. Pengawasan memiliki hubungan dalam kategori sangat tinggi dan positif dengan kinerja, dan disiplin kerja memiliki hubungan yang sangat tinggi kategori dan positif dengan kinerja, serta pengawasan dan pekerjaan disiplin memiliki hubungan dalam kategori sangat tinggi dan positif dengan kinerja (Wasilawati, 2014).

Penelitian lain menyimpulkan sebagai berikut. Pengawasan dan pekerjaan disiplin sebagian berpengaruh signifikan dan pengawasan serta disiplin kerja memiliki berpengaruh secara simultan terhadap kinerja karyawan di Departemen Sumatera Utara (Nasution, 2017). Berkaitan dengan peranan kepala sekolah, dapat dijelaskan hasil penelitian berikut. Kepala sekolah memainkan sebuah peran penting dalam menentukan kebijakan kedisiplinan (Khusni, 2019). Kepala sekolah memiliki kewenangan untuk mendorong atau memoderasi guru untuk 
tetap disiplin. Adapun kewenangannya sebagai berikut. Kedisiplinan yang baik mencerminkan besarnya rasa tanggung jawab seseorang pada tugas-tugas yang diberikan. Kedisipinan mendorong gairah kerja, semangat kerja, dan kinerja baik. Karena itu, kedisiplinan perlu dikelola dengan baik. Untuk meningkatkan dan memelihara kedisiplinan yang baik memag sulit, karena banyak faktor yang dapar mempengaruhinya namun harus terus diupayakan (Mustika, 2018).

Kedisiplinan berpengaruh terhadap Kinerja Guru. Kedisiplinan berasal dari kata disiplin. Istilah disiplin berasal dari bahasa Latin "Disciplina" yang menunjuk pada kegiatan belajar dan mengajar. Kedisiplinan adalah kumpulan atau sistem-sistem peraturan-peraturan bagi tingkah laku (Tu'u, 2004). Kedisiplinan adalah sikap seseorang yang menunjukkan ketaatan atau kepatuhan terhadap peraturan atau tata tertib yang telah ada dan dilakukan dengan senang hati dan kesadaran diri (S.Waji, 2009). Simpulan lain seperti yang dikemukakan oleh Andi Rasdiyanah yaitu kepatuhan untuk menghormati dan melaksanakan suatu sistem yang mengharuskan orang untuk tunduk pada keputusan, perintah atau peraturan yang berlaku (Rasdiyanah, 1995).

Depdikbud membatasi inti disiplin adalah: "Tingkat konsistensi dan konsekuen seseorang terhadap suatu komitmen atau kesepakatan bersama yang berhubungan dengan tujuan yang akan dicapai waktu dan proses pelaksanaan suatu kegiatan " (Depdikbud, 1993). Guru atau tenaga kependidikan, merupakan cermin bagi anak didiknya dalam sikap atau teladan, dan sikap disiplin guru dan tenaga kependidikan akan memberikan warna terhadap hasil pendidikan yang lebih baik (Suarta, 2019).

Beberapa penilitian menunjukkan sebagai berikut. Efikasi berpengaruh terhadap kinerja guru. Semakin tinggi efikasi diri maka semakin tinggi kinerja. Sebaliknya semakin rendah efikasi diri maka semakin rendah kinerja (Aslamiyah, Lahmuddin and Effendy, 2020). Penelitian lain juga menyatakan terdapat hubungan antara efikasi diri dengan kinerja guru SD di gugus IV Kecamatan Pamijahan teruji kebenarnnya. (Haq, Tholkhah and Primarni, 2019).

Kepala sekolah sebagai manajer sekolah perlu juga mengoptimalkan efikasi guru. Salah satu caranya adalah mengadakan supervisi kepala sekolah kepada guru. Hal ini diharapkan mampu memoderasi efikasi guru sehingga meningkatkan kinerja guru. Salah satu indikator peningkatan kinerja guru diantaranya dengan adanya inovasi pembelajaran melalui pengembangan model pembelajaran yang memadukan akses teknologi, khususnya teknologi informasi dan komunikasi (Taufik, 2016).

Namun, dari penelitian-penelitian tersebut di atas tidak satupun menggunakan moderasi supervisi kepala sekolah untuk mengetahui pengaruh proses yang menyertai terhadap kinerja. Baik pengaruh kedisiplinan terhadap kinerja maupun efikasi guru terhadap kinerja guru. Hal tersebut masih diperlukan penelitian tentang pengaruh kedisiplinan dan efikasi guru terhadap kinerja guru yang menyertakan variabel moderasi supervisi kepala sekolah.

Permasalahan peelitian ini bagaimana pengaruh kedisiplinaan dan efikasi guru terhadap kinerja guru dimoderasi supervisi kepala sekolah di SMA Kabupaten Jepara. Tujuannya untuk menguji pengaruh kedisiplinaan dan efikasi guru terhadap kinerja dimoderasi supervisi kepala sekolah pada SMA Kabupaten Jepara

Efikasi guru mempunyai pengaruh terhadap Kinerja Guru. Menurut Bandura, efikasi diri merupakan bagian penting dalam teori sosial kognitif atau efikasi diri sebagai kepercayaan terhadap kemampuan dirinya untuk mencapai hasil. Bandura menggambarkan keyakinan diri sebagai kepercayaan terhadap diri sendiri dalam melakukan suatu tindakan guna menghadapi suatu situasi sehingga dapat memperoleh hasil seperti yang diharapkan (Haq, Tholkhah and Primarni, 2019).

Seseorang yang memiliki self efficacy yang tinggi dapat mencurahkan semua usaha dan perhatiannya untuk mencapai tujuan yang telah ditentukan, sedangkan individu yang memiliki self efficacy yang rendah cenderung malas untuk berusaha ketika menghadapi situasi yang sulit. Self efficacy dapat ditumbuhkan dan dipelajari malalui 4 sumber yaitu kinerja masa lalu, model 
perilaku mengamati orang lain yang melakukan tindakan yang sama, persuasi dari orang lain dan keadaan fisiologis dan emosional (Bandura, 1997).

Diyakini Robotham dalam Wiryo Raharjo pula kompetensi yang diperlukan oleh seseorang tersebut dapat diperoleh baik melalui pendidikan formal maupun pengalaman (Wiryo Raharjo, 2016). Supervisi Kapala sekolah dapat moderasi kedisiplinan dan efikasi guru. Menurut S. Wajowasito dan W.J.S Poerwadarminta yang dikutip oleh Direktorat Tenaga Kependidikan yaitu Supervisi dialihbahasakan dari perkataan Bahasa Inggris "Supervision" artinya pengawasan. Individu yang menjalankan tugas penyupervisi pendididikan disebut supervisior. Seorang supervisior harus profesional dan akan lebih baik jika ia memiliki jabatan yang lebih tinggi atau lebih berwibawa diantara tenaga pendidik dan tenaga kependidikan lainnya seperti kepala sekolah (Nasional, 2008). Supervisi pendidikan berperan untuk mengawasi kegiatan jalannya pendidikan, dan memperbaiki kekekurangan dan kesalahan dalam proses pendidikan untuk meningkatkan mutu pendidikan. Supervisior berperan mengawasi, memimpin, membina, mengontrol sumber daya yang meliputi perencanaan, pengamatan, pembinaan dan pengawasan (Rahmat, 2018).

Inti dari pengertian tentang supervisi kepada guru atau biasa disebut dengan supervisi akademik. Supervisi akademik merupakan serangkaian kegiatan membantu guru mengembangkan kemampuannya dalam mengelola proses pembelajaran sehingga dapat meningkatkan kompetensi.(Kemdikbud, 2018)

Sasaran Kerja Pegawai (SKP) yang diberi bobot nilai sebesar 60 persen, yaitu kuantitas merupakan ukuran jumlah atau banyaknya hasil kerja yang dicapai oleh seorang pegawai, kualitas merupakan ukuran mutu setiap hasil kerja yang dicapai oleh seorang pegawai, waktu adalah merupakan ukuran lamanya proses hasil kerja yang dicapai oleh seorang pegawai, biaya merupakan besaran jumlah anggaran yang digunakan setiap hasil kerja oleh seorang pegawai (Zubaidah and Yuliana, 2017). Beberapa pengertian tentang kinerja dapat dijelaskan sebagai berikut. Kinerja adalah tingkat hasil kerja karyawan dalam mencapai persyaratan-persyaratan pekerjaan yang diberikan (Henry Simamora, 1995). Kinerja adalah hasil kerja yang dapat dicapai oleh seseorang atau sekelompok orang dalam suatu organisasi, sesuai dengan wewenang dan tanggung jawab masing-masing, dalam rangka mencapai tujuan organisasi (Prawirosentono, 1999).

Dari beberapa pengertian di atas dapat disimpulkan bahwa pengertian kinerja adalah hasil kerja yang dapat dicapai oleh seseorang atau sekelompok orang dalam suatu organisasi, sesuai dengan wewenang dan tanggung jawab masing-masing, dalam rangka mencapai tujuan organisasi yang bersangkutan (Tohirin, 2018). Realita kinerja dapat dipengaruhi oleh kedisiplinan, efikasi dan supervisi kepala sekolah di SMA Kabupaten Jepara..

\section{METODE PENELITIAN}

Populasi dari penelitian ini adalah semua guru Sekolah Menengah Atas Kabupaten Jepara Provinsi Jawa Tengah Jumlah guru yang terdata peneliti 709 orang lebih. Penelitian ini mengunakan Accidental Sampling. Menurut Sugiyono (2009:85), Accidental Sampling adalah teknik penentuan sampel berdasarkan kebetulan, yaitu guru SMA yang secara kebetulan/insidental bertemu yang kebetulan ditemui itu cocok sebagai sumber data untuk digunakan peneliti sebagai sampel. Sampel ( Sampling) adalah suatu cara pengumpulan data yang sifatnya tidak menyeluruh, yaitu tidak mencakup seluruh objek penelitian (populasi) akan tetapi sebagian saja dari populasi (Sugiyono, 2016). Sampel penelitian ini diambil hasil penyebaran angket 28 Februari 2021 samapai 4 Maret 2021 yang mengirim jawaban angket pada google classroom via email. Populasi yang bersifat homogen, yakni populasi yang unsurunsurnya memiliki sifat yang sama, sehingga tidak perlu dipersoalkan jumlahnya secara kuantitatif (Margono, 2004). Populasi dalam penelitian ini adalah guru SMA Kabupaten Jepara bersifat homogin. Untuk itu penentuan jumlah sampel tidak didasarkan pada jumlah sampel akan tetapi lebih menekankan pada alat analisis. 
Adapun sampel yang masuk dalam kurun waktu tersebut sebanyak 95 0rang di ambil secara acak melalui email yang masuk tercepat. Metode pengumpulan data adalah menggunakan kuesener skala likert. Skala likert yaitu skala yang digunakan untuk mengukur sikap, pendapat, dan persepsi seseorang atau sekelompok orang tentang fenomena sosial (Sugiyono, 2016). Jenjang 1 sampai dengan 5 dengan rentang skala adalah sebagai berikut: Skala 1 untuk jawaban Sangat Tidak Setuju (STS) dengan skor 1. Skala 2 untuk jawaban Tidak Setuju (TS) dengan skor 2, Skala 3 untuk jawaban Cukup Setuju (CS) dengan skor 3, Skala 4 untuk jawaban Setuju (S) dengan skor 4, Skala 5 untuk jawaban Sangat Setuju (SS) dengan skor 5

Variabel penelitian ini adalah variabel independen dan variabel dependen serta variabel moderasi. Variabel moderasi (moderating) adalah variabel yang mempunyai pengaruh terhadap sifat atau arah hubungan antar variabel (Liana, 2009).

Variabel independen kedisiplinan dan efiasi guru sebagai prediktor yang dilambangkan dengan X1 dan X2. Variabel dependen adalah kinerja guru (dependent variable) dilambangkan $\mathrm{Y}$, sedangkan variabel moderasi dilambangkan $\mathrm{Z}$.

Persamaan penelitian ini menggunakan Moderated Regression Analysis (MRA) dengan persamaan sebagai berikut (Sharma, 1981). Persamaan ini sesuai Model menggunakan pure moderator dengan persamaan sebagai berikut: $Y=a+b 1 X 1+b 2 X 2+b 3(X 1-Z)+b 3(X 2-Z)+$ e; dimana: $\mathrm{Y}=$ variabel dependen (Kinerja Guru) $\mathrm{X} 1=$ variabel independen pertama ( kedisiplinan ), $\mathrm{X} 2=$ variabel independen kedua (Efikasi guru), $\mathrm{Z}=$ variabel moderasi ( supervisi kepala sekolah $),(\mathrm{X} 1-\mathrm{Z})=$ pengruangan $\mathrm{X} 1$ dan $\mathrm{Z},(\mathrm{X} 2-\mathrm{Z})=$ pengurangan $\mathrm{X} 2$ dan $\mathrm{Z}$ dan $\mathrm{e}=$ error terms .

Dalam penelitian ini akan digunakan metode analisis selisih mutlak yakni analisis variabel moderasi dengan meregresikan selisih mutlak variabel indipenden terstandarisasi dengan variabel moderasi terstandarisasi. Jika variabel selisih mutlak antara variabel bebas terstandarisasi dengan variabel moderasi terstandarisasi signifikan maka dapat disimpulkan variabel moderasi benar-benar memoderasi hubungan variabel bebas dengan variabel terikatnya (Suliyanto, 2011).

\section{HASIL DAN PEMBAHASAN}

Hasil

Berdasarkan 95 data kuisener dari guru SMA Kabupaten Jepara yang dapat diringkas dalam tabel statistik sebagai berikut;

Tabel 1. Data Statistik Responden

\begin{tabular}{|c|c|c|c|c|c|c|}
\hline & & & Statistic & & & \\
\hline & & $\begin{array}{c}\text { Jeniis } \\
\text { Kelamain }\end{array}$ & Usia & Pendidikan & Golongan & Masa Kerja \\
\hline $\mathrm{N}$ & Valid & 95 & 95 & 95 & 95 & 95 \\
\hline & Missing & 0 & 0 & 0 & 0 & 0 \\
\hline & & 1.5158 & 2.7053 & 2.1263 & 3.2632 & 2.1474 \\
\hline & & 2.0000 & 3.0000 & 2.0000 & 3.0000 & 2.0000 \\
\hline M & & 2.00 & 3.00 & 2.00 & 5.00 & 3.00 \\
\hline & iation & .50240 & 1.06065 & .33397 & 1.36218 & .89880 \\
\hline & & 1.00 & 1.00 & 2.00 & 1.00 & 1.00 \\
\hline & & 2.00 & 4.00 & 3.00 & 5.00 & 4.00 \\
\hline
\end{tabular}

Sebanyak 95 orang dan semua valid yang ditunjukkan pada data missing nol semua pada tabel. Data responden tersebut dikelompokkan berdasarkan jenis kelamin, usia, pendidikan, golongan, dan masa kerja. 
Deskripsi jenis kelamin perempuan lebih dominan dengan mencapai 51,6 persen sementara laki-laki sebanyak 48,4 persen. Deskripsi usia kerja didominasi oleh usia 41-50 tahun sebanyak 30,5\%, kemudian disusul pada usia 51-60 tahun sebanyak 28,4\%, Kemudian kemudian usia 31-40 tahun sebanyak 24,2\% serta usia 21-30 tahun sebanyak 16,8\%.Deskripsi pendidikan S1 mendominan dengan 87,4 sementara S2 baru mencapai 12,6 persen. Golongan lainnya ini untuk pengelompokan pada responden yang belum menjadi pegawai negeri sipil. Dari deskripsi golongan reseponden justru responden golongan lainnya yang terbanyak yakni mencapai 33,7\% yaitu guru yang belum menjadi PNS, disusul golangan IIIc-IIId sebanyak 29,5 $\%$, golongan IVa-IVb sebesar 29,5\%, golongan IIIa-IIIb sebesar 6,7\% dan yang paling sedikit adalah golongan IVc-IVd sebesar 1,1\%. Deskripsimasa kerja 21-30 terbanyak yakni sebesar $35,8 \%$, disusul masa kerja 1-10 sebesar 29,5 tahun dan 11-20 sama-sama sebesar 30,5\% serta yang paling sedikit masa kerja 31-40 tahun sebesar 4,2\%.

\section{Deskripsi Varibel Penelitian}

Variabel penelitan ini meliputi empat variabel yakni variabel kedisiplinan ,efikasi kerja , supervisi kepala sekolah dan kinerja guru. Gambaran Statistik meliputi nilai rata-rata, median. Mode dan standar deviasi adalah sebagai berikut. Khusus mean dikategorikan rendah (1-2,33), sedang $(2,33-3,66)$, dan tinggi $(3,66-5)$.Secara garis besar dapat dijelaskan sebagai berikut. 1) Respnden 95 dan mengisi varibel x1 semua dengan missing 0. Sembilan faktor X1.1 sampai X1.9. Dengan rata-rata X1 4,45 termasuk dalam kategori tinggi. 2) Efikasi yang merupakan variabel tentang keyakinan diri ini ada 19 item faktor dan semuanya terisi dengan missing nol dan rata-rata skala jawaban angket 4,32 termasuk kategori tinggi. 3) Supervisi kepala sekolah ada 11 item dengan missing nol. Skor rata-rata sebesar 4,35 termasuk pada kategori tinggi. 4) Kinerja guru ada 11 item dengan missing nol. Skor rata-rata sebesar 4,36 termasuk pada kategori tinggi.

\section{Analisis Data Penelitan Uji Validitas}

Teknik Analisis Faktor Sarwono (2012:202), Analisis faktor adalah analisis yang digunakan untuk melakukan pengurangan data atau kata lain melakukan peringkasan atau pengelompokan data atau variabel menjadi lebih kecil jumlahnya. Dengan indeks dari KMO adalah antara 0.5 sampai 1.0 dengan ketentuan jika nilai KMO dibawah 0.5 menyatakan bahwa korelasi antara pasangan variabel atau indikator tidak dapat dijelaskan oleh variabel atau indikator lainnya dan dengan demikian berarti analisis faktor tidak tepat, demikian pula sebaliknya, apabila nilai KMO lebih besar dari 0.5 maka analisis faktor dapat digunakan (Sarwono, 2012).

Melalui program SPSS dengan alat uji Kaiser-Meyer-Olkin of sampling adequacy (KMO MSA). Nilai KMO bervariasi Antara 0 (nol) sampai satu (1) dengan kriteria: 1) Apabila $\mathrm{KMO}>0,5$ maka ketercukupan sampel terpenuhi. 2) Apabila loading factor $>0,4$ maka indikator valid.

\section{Uji Validitas Variabel Kedisiplinan (X1)}

Hasil pengujian validitas variabel kedisiplinan dengan menggunakan KMO and Bartlett's Test mendapatkan hasil sebagai berikut.

Tabel 2. KMO and Bartlett's Test X1

\begin{tabular}{llr}
\hline \multicolumn{2}{c}{ Kaiser-Meyer-Olkin Measure of Sampling } & 0,880 \\
Adequacy. & & \\
Bartlett's Test of & Approx. Chi-Square & 515,914 \\
Sphericity & Df & 21 \\
& Sig. & 0,000 \\
\hline
\end{tabular}


Dari hasil uji KMO tampak dalam tabel tersebut bahwa angka melebihi batas 0,5 seperti yang ditetapkan. Angka hasil uji sebesar 0,850 ini jelas ketercukupan sampel terpenuuhi. Dari hasil kevalidan dapat disimpulkan loading faktor masing-masing iten soal pada variabel kedisiplinan X1.1 Sampai X1.7 valid semua. Terbukti hasil tidak ada satupun di bawah ketentuan yakni 0,40 .

\section{Uji Validitas Variabel Efikasi Guru ( X2)}

Hasil pengujian validitas variabel efikasi guru dengan menggunakan KMO and Bartlett's Test mendapatkan hasil sebagai berikut.

Tabel 3 KMO and Bartlett's Test X2 KMO and Bartlett's Test

\begin{tabular}{llr} 
Kaiser-Meyer-Olkin Measure of Sampling Adequacy. & 0,866 \\
Bartlett's Test of & Approx. Chi-Square & 1093,873 \\
Sphericity & Df & 171 \\
& Sig. & 0,000 \\
\hline
\end{tabular}

Dari hasil uji KMO tampak dalam tabel tersebut bahwa angka melebihi batas 0,5 seperti yang ditetapkan. Angka hasil uji KMO sebesar 0,866, ini dapat dikatakan ketercukupan sampel terpenuhi. Sementara bila di lihat dari komponen matriks loading factor adalah sebagai berikut. Dari hasil uji dapat disimpulkan loading faktor masing-masing item soal pada variabel kedisiplinan X2.1 Sampai X2.19 valid semua. Terbukti dari hasil tidak ada satupun yang di bawah ketentuan yakni 0,40.

Uji Validitas Variabel Supervisi Kepala Sekolah ( Z)

Hasil pengujian validitas variabel supervisi kepala sekolah dengan menggunakan KMO and Bartlett's Test mendapatkan hasil sebagai berikut .

Tabel 4 KMO and Bartlett's Test Z KMO and Bartlett's Test

\begin{tabular}{llr} 
Kaiser-Meyer-Olkin Measure of Sampling Adequacy. & 0,909 \\
Bartlett's Test of Sphericity & Approx. Chi-Square & 637,800 \\
& Df & 55 \\
& Sig. & 0,000 \\
\hline
\end{tabular}

Dari hasil uji KMO tampak dalam tabel tersebut bahwa angka melebihi batas 0,5 seperti yang ditetapkan. Angka hasil uji sebesar 0,909, ini jelas ketercukupan sampel terpenuhi. Sementara bila di lihat loading faktor masing-masing iten soal pada variabel kedisiplinan Z1 Sampai Z11 valid semua. Terbukti dari hasil tidak ada satupun yang di bawah ketentuan yakni 0,40 .

\section{Uji Validitas Kinerja Guru ( Y)}

Hasil pengujian validitas variabel kinerja guru dengan menggunakan KMO and Bartlett's Test mendapatkan hasil sebagai berikut .

Tabel 5 KMO and Bartlett's Test Y

KMO and Bartlett's Test

\begin{tabular}{lrr}
\hline \multicolumn{2}{l}{ Kaiser-Meyer-Olkin Measure of Sampling } & 0,850 \\
Adequacy. & & \\
Bartlett's Test of & Approx. Chi-Square & 548,745 \\
Sphericity & Df & 55 \\
& Sig. & 0,000 \\
\hline
\end{tabular}

Dari hasil uji KMO tampak dalam tabel tersebut bahwa angka melebihi batas 0,5 seperti yang ditetapkan. Angka hasil uji sebesar 0,850, ini dinyatakan ketercukupan sampel terpenuhi Sementara bila di loading faktor masing-masing iten soal pada variabel kedisiplinan Y1 Sampai Y11 valid semua. Terbukti dari hasil tidak ada satupun yang di bawah ketentuan yakni 0,40. 


\section{Uji Reliabelitas}

Untuk uji reliabilitas digunakan Cronbach alpha. Untuk mengukur tingkat reliabilitas data menggunakan rumus Alpha Cronbach. Jika Cronbach alpha > 0,6 maka variabel reliabel, dan jika Cronbach alpha < 0,5 maka variabel tidak reliabel (Arikunto, 1996). Ketentuan terbaru $>0,7$.

Pengujian Reliabelitas Varibel Independen Kedisplinan ( X1)

\section{Tabel 6 Reliabilitas Kedisiplinan X1}

Reliability Statistics

\begin{tabular}{ccc}
\hline & Cronbach's Alpha Based on & \\
Cronbach's Alpha & Standardized Items & N of Items \\
0,907 & 0,907 & 7 \\
\hline
\end{tabular}

Dari tabel tersebut tampak bahwa Cronbach's Alpha lebih besar dari 0,7 yakni 0,907 sehingga dapat dikatakan reliabel.

Pengujian Reliabelitas Varibel Independen Efikasi Guru ( X2)

Hasil pengujian pada variabel ini tampak tampak pada tabel berikut:

Tabel 7 Reliabilitas Statistic X2

\begin{tabular}{|c|c|c|}
\hline & $\begin{array}{l}\text { Reliability Statistics } \\
\text { Cronbach's Alpha }\end{array}$ & \\
\hline $\begin{array}{l}\text { Cronbach's } \\
\text { Alpha }\end{array}$ & $\begin{array}{c}\text { Based on Standardized } \\
\text { Items }\end{array}$ & $\mathrm{N}$ of Items \\
\hline 0,933 & 0,934 & 19 \\
\hline
\end{tabular}

Dari tabel tersebut tampak bahwa Cronbach's Alpha lebih besar dari 0,7 yakni 0,933 sehingga dapat dikatakan reliabel. Varibel Independen Efikasi Guru seluruhnya reliabel

\section{Pengujian Reliabelitas Varibel Moderasi Supervisi Kepala Sekolah}

Tentang pengujian variabel ini tampak pada tabel berikut ini.

Tabel 8 Reliabilitas Statistik Z

\begin{tabular}{ccc}
\hline & Reliability Statistics \\
Cronbach's & Cronbach's Alpha Based on & $\mathrm{N}$ of \\
Alpha & Standardized Items & Items \\
0,921 & 0,921 & 11 \\
\hline
\end{tabular}

Dari tabel teksebut tampak bahwa Cronbach's Alpha lebih besar dari 0,7 yakni 0,921 sehingga dapat dikatakan reliabel.

Pengujian Reliabelitas Variabel Dependen Kinerja Guru ( Y)

Reliabelitas untuk variabel tersebut adalah sebagai berikut.

Tabel 9 Reliabilitas Statistik Y

\begin{tabular}{ccc}
\hline & Reliability Statistics & \\
Cronbach's & Cronbach's Alpha Based on & $\mathrm{N}$ of \\
Alpha & Standardized Items & Items \\
0,883 & 0,886 & 11 \\
\hline
\end{tabular}

Dari tabel teksebut tampak bahwa Cronbach's Alpha lebih besar dari 0,7 yakni 0,883 sehingga dapat dikatakan reliabel.

\section{Uji Normalitas Data}

Pada uji normalitas dapat menggunakan Kolmogorov-Smirnov. Menurut Ghozali (2009) mengungkapkan bahwa tujuan dari uji normalitas adalah untuk menguji apakah model regresi, variabel pengganggu atau residual memiliki distribusi normal. Normalitas ini dapat dideteksi dengan menggunakan uji statistik non-parametrik kolmogrov-smirnov K-S, apabila signifikansi lebih besar dari $\alpha=0,05$ (Ghozali, 2009). 
Pada uji normalitas ini meliputi variabel kedisiplinan (x1) ,efikasi guru (x2) dan supervisi kepala sekolah (z) yang mempengaruhi kinerja guru.(y). Pada variabel x1, x2, dan z skornya dimutlakkan.

Tabel 10 Normalitas Data

One-Sample Kolmogorov-Smirnov Test

\begin{tabular}{llr}
\hline & \multicolumn{1}{c}{ Unstandardized Residual } \\
$\mathrm{N}$ & & 95 \\
Normal & Mean & .00000000 \\
Parameters ${ }^{\mathrm{a}, \mathrm{b}}$ & Std. & .56836351 \\
& Deviation & \\
Most Extreme & Absolute & .059 \\
Differences & Positive & .059 \\
& Negative & -.046 \\
Test Statistic & .576 \\
Asymp. Sig. (2-tailed) & $.895^{\mathrm{c}, \mathrm{d}}$ \\
a. Test distribution is Normal. \\
b. Calculated from data. \\
c. Lilliefors Significance Correction. \\
d. This is a lower bound of the true significance. \\
\hline
\end{tabular}

Dari tes Kolmogorov-Sminav (KS) berdasarkan tabel taraf signifikansiya >0,05.Dalam lebih besar dari ketentuan yaiitu 0,895 lebih besar dari 0,05. Dapat katakan model regresi variabel dependen dan indipenden terdistribusi normal. Karena berdistribusi normal maka dapat dilanjutkan pada uji berikutnya.

\section{Uji Heteroskedastisitas Data}

Heteroskedastisitas data menggunakan uji Gletser dengan ketentuan 1) jika signifikansi (sig) lebih besar dari 0,05, maka kesimpulannya adalah tidak terjadi heteroskedastisitas dalam uji regesi, sebaliknya bila signifikansi (sig) lebih kecil dari 0,05, maka kesimpulannya adalah terjadi heteroskedastisitas dalam uji regesi.

\section{Tabel 11 Heteroskedastisitas Data}

\begin{tabular}{|c|c|c|c|c|c|c|}
\hline & & Coeff & cients $^{a}$ & & & \\
\hline & & Unstandar & lized & Standardized & & \\
\hline & & Coeffici & nts & Coefficients & & \\
\hline & & & Std. & & & \\
\hline & & B & Error & Beta & $\mathrm{T}$ & Sig. \\
\hline 1 & (Constant) & -2.893 & .380 & & -7.603 & .000 \\
\hline & Zscore: &.-163 & .460 & -..073 & -354 & .724 \\
\hline & Kedisiplinan & & & & & \\
\hline & Zscore: Efikasi & .118 & .443 & .053 & .265 & .791 \\
\hline & Guru & & & & & \\
\hline & Zscore: & .040 & .598 & 019 & .056 & .947 \\
\hline & Supervisi KS & & & & & \\
\hline & Zscore: Kinerja & .181 & .489 & .083 & .370 & .712 \\
\hline & Zscore(X1_Z) & .277 & .613 & .051 & .452 & .652 \\
\hline & Zscore(X2_Z) & .989 & .607 & .187 & 1.629 & .107 \\
\hline & ependent Variab & nresid & & & & \\
\hline
\end{tabular}

Berdasarkan hasil uji diketahui bahwa signifikasnsi output Coefficients ${ }^{a}$ mean $\mathrm{x} 1$ (Zscore kedisiplinan) sebesar 0,724 dan mean x2 ( Zscore efikasi guru) sebesar 0,791, Zscore supervisi KS sebesar 0,947, Zscore kinerja sebesar 0,712, Zscore(X1_Z) sebesar 0,652 serta 
score (X2_Z) sebesar 0,107. Semuanya variabel > 0,05 Dengan demikian dapat disimpulkan tidak terjadi gejala heteroskedasitistas atau terbebas dari heteroskedasitistas.

\section{Uji Model}

Uji Model Pada uji model ada dua uji yaitu: (1) Uji F, berfungsi untuk menguji kelayakan atau kesesuaian model. Jika signifikansi $\mathrm{F}<0,05$ dan hasil uji $\mathrm{F}>0,05$ maka model dinyatakan memenuhi goodness of fit model.

Tabel 12 Uji F Anova

\begin{tabular}{|c|c|c|c|c|c|c|}
\hline & $\begin{array}{l}\text { Sum of } \\
\text { Squares }\end{array}$ & Df & \multicolumn{2}{|l|}{ Mean } & \multirow{2}{*}{$\begin{array}{l}\text { Sig. } \\
.000 \mathrm{a}\end{array}$} \\
\hline \multirow[t]{3}{*}{1} & Model & 62.605 & 4 & 15.651 & 46.389 & \\
\hline & Residual & 30.565 & 90 & .337 & & \\
\hline & Total & 92.971 & 94 & & & \\
\hline
\end{tabular}

Dari uji F model dapat dilihat bahwa nilai $\mathrm{F}$ sebesar 46,389 pada sig $0,000<0,05$ artinya model regresi yang digunakan untuk melihat pengaruh variabel $Z$ scoere kedisiplinan, $\mathrm{Z}$ score efikasi guru, moderasi 1 ( X1_Z), moderasi 2 (X1_Z) memenuhi goodness of fit model ( kesesuaian model yang berpengaruh terhadap kinerja guru).

Uji Koefisien Determinasi/ R Square

Uji koefisien determinasi atau uji R Square dilakukan untuk mengetahui sejauh mana variasi variabel indipenden yang ada dalam model dapat menerangkan pengaruhnya terhadap variabel dependen.

Tabel 13 Uji R2 (R Square )

\begin{tabular}{|c|c|c|c|c|c|}
\hline Model & $\mathrm{R}$ & R Square & $\begin{array}{l}\text { Adjusted R } \\
\text { Square }\end{array}$ & $\begin{array}{l}\text { Std. Error of the } \\
\text { Estimate }\end{array}$ & $\begin{array}{l}\text { Durbin- } \\
\text { Watson }\end{array}$ \\
\hline 1 & $.821 \mathrm{a}$ & .673 & .659 & .58085651 & 2.223 \\
\hline \multicolumn{6}{|c|}{$\begin{array}{l}\text { a. Predictors: (Constant), x2_z, Zscore: Kedisiplinan, x1_z, Zscore: Efikasi } \\
\text { Guru } \\
\text { b. Dependent Variable: Zscore: Kinerja Guru }\end{array}$} \\
\hline
\end{tabular}

Dari tabel di atas dapat dilihat bahwa adjusted R Square adalah 0,659 yang artinya sebesar 65,9\% variabel indivenden mampu menjelaskan variabel dependen, sedangkan 44,1\% dijelaskan faktor lain di luar variabel indipenden.

\section{Uji Parsial (Uji t)}

Pengajuan hipotesis dilakukan dengan menganalisis persamaan regresi untuk mengetahui seberapa besar koefisen regresinya. Kriteria hasil uji hipotesis ini adalah apabila nilai sig $<0,05$ dengan nilai $\beta$ positif maka hipotesis diterima, namun bila nilai sig $>0,05$ dan nilai $\beta$ negatif maka hipotesis ditolak. Hasil uji hipotesis parsial ( Uji t ) dapat dilihat pada tabel berikut. 


\section{Tabel 14 Uji t}

\begin{tabular}{|c|c|c|c|c|c|}
\hline \multirow[b]{2}{*}{ Model } & \multicolumn{3}{|l|}{$\begin{array}{l}\text { Standardized } \\
\text { Coefficients }\end{array}$} & \multicolumn{2}{|c|}{ Collinearity Statistics } \\
\hline & Beta & $\mathrm{T}$ & Sig. & Tolerance & VIF \\
\hline $1 \quad$ (Constant) & & 1.140 & .257 & & \\
\hline Zscore: & .338 & 3.424 & .001 & .371 & 2.693 \\
\hline Kedisiplinan & & & & & \\
\hline Zscore: Efikasi & .508 & 5.194 & .000 & .379 & 2.2636 \\
\hline Guru & & & & & \\
\hline $\mathrm{x} 1 \_\mathrm{z}$ & .002 & .031 & .975 & .885 & 1.130 \\
\hline x2_z & -.152 & $-2,382$ & .019 & .888 & 1.126 \\
\hline Dependent Variabl & ore: Kineria C & & & & \\
\hline
\end{tabular}

Simpulan hasil uji hipotesis parsial (Uji t) sebagai berikut.

H1: Kedisipilnan berpengaruh positif dan signifikan terhadap kinerja guru . Hasil memiliki nilai sig $0,001<0,05$ dengan standardized coefficient beta $\beta$ positf 0,338 . Dengan demikain hipotesis 1 diterima. Hal itu dapat disimpukan bahwa Kedisipilnan berpengaruh positif dan signifikan terhadap kinerja guru.

H2: Efikasi guru berpengaruh positif dan signifikan terhadap kinerja guru.. Hasil memiliki nilai sig $0,000<0,05$ dengan standardized coefficient beta $\beta$ positf 0,508 . Dengan demikain hipotesis 2 diterima. Hal itu dapat disimpukan bahwa efikasi guru berpengaruh positif dan signifikan terhadap kinerja guru.

H3: Supervisi kepala sekolah memoderasi pengaruh kedisiplinan terhadap kinerja guru. Hasil memiliki nilai sig $0,975>0,05$ dengan standardized coefficient beta $\beta$ positif 0,002 . Dengan demikain hipotesis 3 ditolak. Hal itu dapat disimpukan bahwa Supervisi kepala tidak memoderasi pengaruh kedisiplinan terhadap kinerja guru.

H4: Supervisi kepala sekolah memoderasi efikasi guru terhadap kinerja guru . Hasil uji memiliki nilai sig $0,019<0,05$ dengan standardized coefficient beta $\beta$ negatif 0,152 . Dengan demikain hipotesis 4 ditolak. Hal itu dapat disimpulkan bahwa supervisi kepala sekolah memoderasi efikasi guru.

\section{Pembahasan}

Beberapa penilitian terdahulu menyimpulkan bahwa kedisiplinan berpengaruh terhadap kinerja. Dari hasil uji hipotesis 1 juga juga terbukti berpengaruh positif dan signifikan. Dengan demikian selaras dengan penelitian terdahulu. Sementara pada hipotsis 2 juga selaras dengan penelitian terdahulu yakni efikasi terbukti berpengaruh terhadap positif dan signifikan terhadap kinerja. Namun dalam hipotesis 3 dan 4 tidak terbukti supervisi berpengaruh memoderasi kedisiplinan terhadap kinerja dan tidak terbukti memoderasi efikasi terhadap kinerja.

Berdasarkan kenyataan di lapangan fenomena yang terjadi golongan guru non-PNS di Kabupaten Jepara belum sepenuhnya diberlakukan penilaian kinerja guru tiap tahunnya. Tidak seperti yang PNS tiap tahun selalu melakukan penilaian kinerja guru untuk mengumpulkan angka kridit tahunan untuk kenaikan pangkat. Guru yang belum PNS walau belum merasakan dampak langsung supervisi terhadap kinerja guru. Upaya untuk meningkatkan kualitas guru masih belum maksimal terwujud, hal ini dilihat dari banyaknya guru yang masih melakukan pelanggaran disiplin kerja yang bisa ditemui di media elektronik, media cetak maupun di lapangan (Karmini and Suniasih, 2021).

Fenomena yang terjadi dari uji validitas dan uji reliabelitas dengan rata-rata tinggi namun dua hipotesis tidak diterima. Seharus beranjak dari validitas, reliabilitas tinggi maka hipotesis bisa diterima semua. Apalagi didukung oleh uji normalitas dan tidak terjadi heteroskedastisitas yang terpenuhi. 
Pada adjusted $R$ Square sebesar 65,9 \% variabel indivenden mampu menjelaskan variabel dependen, sedangkan 44,1\% dijelaskan faktor lain di luar variabel indipenden Ada kemungkinan 44,1 \% yang tidak mampu dijelaskan dalam model ini adalah hal responden yang tidak merasakan dampak langsung seupervisi kepala sekolah tersebut sehingga supervisi kepala sekolah tidak terbukti memoderasi kedisiplinan dan efikasi guru terhadap kinerja guru di SMA Kabupaten Jepara tidak terbukti.Hasil penelitian lain menyebutkan sebagai berikut. Supervisi kepala sekolah berpengaruh yang signifikan supervisi kepala sekolah terhadap disiplin kerja guru dengan kontribusinya sebesar $21,75 \%$, maka terdapat faktor lain yang mempengaruhi disiplin kerja guru selain supervisi kepala sekolah (Karmini and Suniasih, 2021).

Sementara itu berkaitan efikasi tersirat dalam hasil penelitian berikut. Berdasarkan perhitungan regresi linear sederhana diperoleh nilai korelasi sebesar 0.606, yang berarti variabel efikasi diri dan etos kerja dengan variabel kepuasan kerja guru memiliki korelasi kuat.Sedangkan determinan varians sebesar 0.367 yang berarti $36.7 \%$ kepuasan kerja guru dipengaruhi oleh efikasi diri dan etos kerja secara bersama-sama dan $63.3 \%$ dipengaruhi oleh faktor lain (Tampubolon and Hutagaol, 2015). Pimpinan sekolah perlu meningkatkan efikasi diri guru dan membangun etos kerja dengan memberikan nasihat, contoh dan masukanmasukan ketika sedang melakukan kegiatan supervisi. Kepala sekolah juga perlu memberikan tantangan-tantangan kerja untuk melatih kepercayaan dan keyakinan diri para guru dalam mengerjakan tugas.

\section{KESIMPULAN}

Simpulan penelitian ini ada dua hipotesis diterima dan dua ditolak. Adapun hasil yakni 1) Kedisiplinan berpengaruh positif dan signifikan terhadap kinerja guru di SMA Kabupaten Jepara. 2) Efikasi guru berpengaruh positif dan signifikan terhadap kinerja guru di SMA Kabupaten Jepara 3) Supervisi kepala sekolah tidak memoderasi pengaruh kedisiplinan terhadap kinerja guru di SMA Kabupaten Jepara, dan 4) Supervisi kepala sekolah berpengaruh tidak memoderasi efikasi guru terhadap kinerja guru di SMA Kabupaten Jepara. Untuk diperlukan kajian yang mendalam tentang moderasi supervisi kepala sekolah pada kedisiplinan, efikasi guru, terhadap kinerja guru pada periode penelitian yang berikutnya.

\section{DAFTAR PUSTAKA}

Arikunto, S. (1996) Prosedur Penelitian: Suatu Pendekatan Praktek. Cetakan ke. Jakarta: :PT. Rineka Cipta.

Bandura (1997) Self Efficacy - The Exercise of Control (Fifth Printing, 2002). New York: W.H. Freeman \& Company.

Depdikbud (1993) Kamus Besar Bahasa Indonesia. Jakarta: Balai Pustaka.

Haq, N., Tholkhah, I. and Primarni, A. (2019) 'Pengaruh Kepemimpinan Kepala Sekolah dan Efikasi Diri Guru Terhadap Kinerja Guru', Reslaj : Religion Education Social Laa Roiba Journal, 1(2), pp. 173-188. doi: 10.47467/reslaj.v1i2.108.

Karmini, N. K. A. and Suniasih, N. W. (2021) 'Kecerdasan Emosional dan Supervisi Kepala Sekolah Beerpengaruh terhadap Disiplin Kerja Guru SD', Jurnal Pedagogi dan Pembelajaran, 4(2). doi: 10.23887/jp2.v4i2.33048.

Kemdikbud (2018) Supervisi Akademik dan Penilaian Kinerja Guru.

Liana, L. (2009) 'Penggunaan MRA dengan Spss untuk Menguji Pengaruh Variabel Moderating terhadap Hubungan antara Variabel Independen dan Variabel Dependen', Jurnal Teknologi Informasi Dinamik, Volume XIV, pp. 90-97.

Margono (2004), Metodologi Penelitian Pendidikan. Jakarta: Rineka Cipta.

Mustika, S. M. W. (2018) 'Pengaruh Disiplin Kerja Terhadap Kinerja Kerja Guru Pada Sekolah Menengah Pertama 6 Ambon', Sentralisasi, 5(2), p. 21. doi: 10.33506/sl.v5i2.56.

Nasional, D. P. (2008) Metode dan Teknik Supervisi. Jakarta: Direktorat Pendidikan ,Direktorat Peningkatan Mutu Pendidikan dan Tenaga Kependidikan.

Nasution, M. I. (2017) 'The Influence of Supervision and Work Discipline on Performance of 
State Civil Apparatur'.

Prawirosentono, S. (1999) Kebijakan Kinerja Karyawan. Yogyakarta: BPFE.

Rahmat, M. F. dan (2018) 'Principal's Managerial Skill In Improving Teachers' Performance', https://doi.org/10.9790/7388-0803047781, 8(3), 77-8.

Rasdiyanah,

A. (1995) "Pengertian

Disiplin".

http://id.shvoong.com/socialsciences/psychology/2114586-pengertian-disiplin/.

Diakses pada tanggal 4 Januari 2012'.

S.Waji (2009) Pengembangan dan Model Pembelajaran dalam Kurikulum 2013. Jakarta: Prestasi Pustaka.

Sharma, S. (1981) 'Identification and analysis of moderator variables', Journal of Marketing Research (pre-1986); Aug 1981; 18, 000003; ABI/INFORM Globa.

Suarta, P. (2019) Pengaruh Kedisiplinan dan Motivasi Kerja terhadap Kinerja Guru Matematika. Jurnal penelitian matematika dan pendidikan matematika (proximal.

Sugiyono (2016) Metode Penelitian Kuantitatif, Kualitatif dan R\&D. Bandung: PT Alfabet.

Suliyanto (2011) Ekonometrika Terapan: Teori Dan Aplikasi Dengan SPSS. Edisi 1. Yogyakarta: ANDI Yogyakarta.

Tampubolon, R. and Hutagaol, S. (2015) 'Hubungan Antara Efikasi Diri Dan Etos Kerja Dengan Kepuasan Kerja Guru Smak Penabur Harapan Indah Kota Bekasi', Jurnal Manajemen Pendidikan, 4(2), pp. 187-204. Available at: http://ejournal.uki.ac.id/index.php/jmp/article/view/Efikasi Diri\%2C Etos Kerja\%2C Kepuasan Kerja.

Taufik, M. (2016) 'Media Elektonik Portofolio Untuk Meningkatkan Trend Prestasi Belajar Mahasiswa', USEJ - Unnes Science Education Journal, 5(1). doi: 10.15294/usej.v5i1.9559.

Tohirin, T. (2018) 'Pengaru Supervisi dan Disiplin Kerja terhadap Kinerja Guru', Jurnal Mandiri, 2(1), pp. 227-244. doi: 10.33753/mandiri.v2i1.41.

Tu'u, T. (2004) Peran Disiplin pada Perilaku dan Prestasi Belajar. Jakarta: Grasindo.

Wasial Khusni, Mahmudah, F. N. (2019) 'Kemampuan Manajerial Utama dalam Mengembangkan Sekolah Efektif'.

Wasilawati, A. \& (2014) 'Supervision, working discipline, and the performance of the servants of the Central Statistics Agency Central Lampung Regency', The Journal of management and entrepreneurship, 16(2).

Wiryo Raharjo, Y. S. (2016) 'Pengaruh Motivasi dan Kompetensi Profesional guru Dimoderatori Budaya Oraganesaional', Jurhal Pasca Sarjana Unisbank.

Zubaidah and Yuliana, I. (2017) 'Pengaruh Penilaian Prestasi Kerja dan Kedisiplinan Terhadap promosi Jabatan PT Batmec Shipyard’, Jurnal Akuntansi dan Bisnis (Akmenbis), 7(1), pp. 1-12. 